\title{
Rola etyki środowiskowej w edukacji ekologicznej oraz jej implikacje w katechezie
} (referat wygloszony w trakcie obrad konferencji, pt.: Problemy XXI wieku: Edukacja środowiskowa a katecheza - UKSW 25.10.2006 r.)

\section{Wstęp}

W publikacjach z zakresu etyki środowiskowej podkreśla się, że ta dyscyplina normatywna oprócz zadań ściśle teoretycznych jest także dziedziną praktyczną, mającą za zadanie doprowadzić do nawiązania pozytywnych relacji człowieka z przyrodą. Tak postawiony cel może spełnić jedynie przy współudziale edukacji ekologicznej, dla której dostarcza odpowiednio uzasadnionych wartości i moralnych imperatywów ${ }^{1}$. Na tej płaszczyźnie zaznacza się wspólna praca etyków, ekologów i pedagogów. Proces ten może być z powodzeniem realizowany również w obszarze edukacji katechetycznej przy wsparciu nauczycieli religii - katechetów.

\section{Etyka środowiskowa - rozważania natury ogólnej}

Etyka środowiskowa stanowiąca część etyki normatywnej (zamiennie stosowana z pojęciem etyka ekologiczna bądź ekoetyka) dotyczy zasad i norm ochrony, zniszczonej w dużym stopniu przez człowieka przyrody, z uwzględnieniem również stosunku ludzi wobec zwierząt. Ponadto ten współczesny nurt w etyce, określa aktualne tendencje oraz możliwości takiej reorientacji w relacjach człowieka z przyrodą, która pozwoliłaby na utrzymanie równowagi naturalnej.

Naturalnie zadania i cele wpisane w jej przedmiot zasadzają się na silnym związku teoretycznej refleksji z oczekiwaniami natury praktycznej. Do zadań

1 Zob. W. BoŁoz, Etyczne uwarunkowania edukacji ekologicznej rodziny, (w:) Edukacja ekologiczna rodziny. Stan - możliwości - programy. Pod red. W. Bołoza, Warszawa 1995, s.19-29. 
teorii należy bowiem zbudowanie i uzasadnienie odpowiedniego systemu wartości i norm, który następnie za pomocą edukacji ekologicznej zostanie ugruntowany w ludzkiej świadomości, kształtując pozytywne postawy człowieka wobec przyrody ${ }^{2}$.

Ponieważ etyka środowiskowa w swoim zamierzeniu ma stanowić asumpt do działań praktycznych zmierzających do poprawy sytuacji na polu ochrony środowiska społeczno-przyrodniczego, istnieje zatem konieczność rozpatrywania problematyki etycznej łącznie z jej edukacyjnym, pedagogicznym podłożem. Zagadnienie to podejmę w następnym podrozdziale.

\section{Etyka środowiskowa $w$ kontekście pedagogicznym}

Etyka środowiskowa (ekologiczna) wyrosła $z$ uzasadnionych obaw o stan środowiska przyrodniczego i w swych założeniach jest czymś w rodzaju remedium na coraz bardziej pogłębiający się kryzys ekologiczny. Uczeni skupieni wokół tej dyscypliny od samego początku podkreślali, iż oprócz sfery teoretycznej, niezmiernie ważny jest jej zakres praktyczny, mający swe zastosowanie w działaniach edukacyjnych, wychowawczych, spełniającym rolę środka na zło kryzysu ekologicznego. Etycy i pedagodzy zwrócili uwagę, iż nawet najlepiej skonstruowane przepisy prawne, nie przyczynią się do poprawy globalnego stanu przyrody, jeśli nie zostaną uzupełnione zmianą w świadomości i postawach ludzi wobec przyrody.

Określona kondycja środowiska przyrodniczego, jest w dużym stopniu pochodną systemu wartości i norm wyznawanych przez ludzi, a także ich emocjonalnej postawy wobec natury. Nie bez znaczenia jest również poziom wiedzy o środowisku jako ekosystemie. Na tej podstawie można uznać, iż myślenie ekologiczne jest niezbędnym wstępem do rozwoju świadomości ekologicznej. Jeśli bowiem cele edukacji i etyki środowiskowej nie zostaną na trwałe wpisane $\mathrm{w}$ ludzkiej psychice, to ich postulaty nie mają najmniejszych szans powodzenia i na zawsze pozostaną w sferze „pobożnych życzeń”.

Na tej też podstawie za W. Tyburskim przyjąłem, iż świadomość ekologiczna jest dynamiczną strukturą trzech wzajemnie dopełniających się elementów:

a) wiedzy na temat funkcjonowania ekosystemów oraz zależności między przyrodą a społeczeństwem;

b) systemu wartości, zasad i norm postępowania;

c) wrażliwości pozwalającej na przewidywanie ekologicznych skutków własnego działania ${ }^{3}$.

2 W. TyвURsкı, Główne zasady i kierunki etyki środowiskowej, (w:) Wprowadzenie do filozoficznych problemów ekologii. Pod red. A. Papuzińskiego, Bydgoszcz 1999, s. 101.

3 Ibidem, s. 130 . 
Z wyżej zaprezentowanej charakterystyki świadomości ekologicznej wynikają istotne przesłanki na temat celów edukacji ekologicznej. Pierwszy z nich akcentuje w edukacji ekologicznej potrzebę wyposażenia człowieka w niezbędną wiedzę z zakresu ekologii. Mamy tu do czynienia z funkcją poznawczą edukacji ekologicznej.

Ten teoretyczny zasób „suchej” wiedzy z zakresu ekologii i sozologii należy odpowiednio uzasadnić aksjologicznie i normatywnie (zadanie etyki środowiskowej). Nie można bowiem prowadzić właściwej działalności wychowawczej bez uwzględnienia wartości, które powinny być podstawą wszelkiej działalności edukacyjnej i wychowawczej. W aspekcie edukacyjnym wartości są centralnie ulokowanymi przekonaniami o tym, jak jednostka powinna lub nie powinna postępować, lub o pewnym końcowym stanie istnienia wartym lub nie wartym osiągnięcia ${ }^{4}$.

Po tych ogólnych uwagach na temat związków etyki środowiskowej z edukacją (wychowaniem) ekologicznym chciałbym scharakteryzować modele przekazywania treści ekologicznych.

\section{Modele przekazywania treści w ekologii i sozologii}

W mojej opinii treści edukacji ekologicznej powinny bazować nie tylko na dorobku nauk przyrodniczych ale i humanistycznych, zwłaszcza z szerokim uwzględnieniem problematyki filozoficzno-moralnej. Dlatego téz uznałem za zasadne przedstawić swoją autorską wersję filozofii edukacyjnej na gruncie ekologii i ukazać ją z perspektywy trzech modeli edukacyjnych, które określiłem jako: model scjentystyczno-technokratyczny, model aksjologiczno-perswazyjny oraz model aksjologiczno- scjentystyczny (systemowy). Myślę, iż warto je pokrótce scharakteryzować5.

$\mathrm{Z}$ mojego doświadczenia wynika, iż programy zajęć z przedmiotu edukacja ekologiczna realizowane są zwykle w modelu scjentystyczno-technokratycznym. Tradycyjna edukacja ekologiczna budowana jest w oparciu o przyrodniczy model poznawczy, ponieważ ma za zadanie dostarczyć tylko niezbędnych „suchych" wiadomości na temat funkcjonowania przyrody oraz przedstawienia opisu globalnych zagrożeń ekologicznych, a także nowoczesnych technik jej ochrony. Wiedzy tej następnie wymaga się od uczniów, w postaci różnego rodzaju sprawdzianów. Takie podejście jest jednak zbyt płytkie, ponieważ nawet najlepiej wy-

4 R. KuLIK, Jak kształtować postawy proekologiczne. Trening grupowy w edukacji ekologicznej, Katowice 2001, s.29-30.

5 M. CIszek, Filozoficzne modele realizowania treści ekologicznych, (w:) Filozoficzne wizje i modele świata. Pod red. W. Kamińskiej i S. Konstańczaka, Słupsk 2002, s.73-79. Por. A. Papuziński, Świadomość ekologiczna a kultura, (w:) Wprowadzenie do filozoficznych problemów ekologii, op. cit., s.186-204. 
edukowani uczniowie, wcale nie muszą chcieć chronić przyrody, ponieważ sama wiedza, jest nie wystarczająca jeśli nie pobudzimy sfery uczuciowej człowieka, na trwałe wpisując w ich świadomość, chęć do działań ochroniarskich.

Trzeba bowiem naturę ukazać jako pewną wartość, a nie tylko jak zbiornik potrzebnych surowców naturalnych. Ten paradygmat edukacyjny, ma swoje korzenie w filozofii i jest dziedzictwem paradygmatu Kartezjańsko - Newtonowskiego. Główną zasadą tego modelu jest przekonanie, iż „to co technika zepsuła, technika jest również w stanie naprawić”. Stan degradacji środowiska przyrodniczego jest więc w pewnym sensie przysłowiowym „wypadkiem przy pracy"6. Brakuje w tym modelu jakiejś głębszej, interdyscyplinarnej refleksji dotyczącej przyczyn kryzysu ekologicznego. Akcentuje się więc tutaj treści ekologiczne z perspektywy skrajnie rozumianego antropocentryzmu.

Naczelnym hasłem tego paradygmatu, jest przekonanie o pierwszeństwie ekonomiki nad etyką, a co za tym idzie wartości ekonomicznych przed wartościami moralnymi? .

Model scjentystyczny jak przystało na pozytywistyczną koncepcję nauki wyłącza $z$ zakresu swoich badań rozważania metafizyczne i aksjologiczne, dlatego też moim zdaniem nie może zostać uznany za pożądany paradygmat w edukacji ekologicznej. Uważam, iż nie można prowadzić właściwej działalności wychowawczej bez uwzględnienia wartości, które powinny być podstawą edukacji, które następnie należy ugruntować w świadomości wychowanków, w celu rozbudzenia ich wrażliwości. Nawet najlepsze proekologiczne przepisy prawne oraz metody rekultywacji i recyklingu, nie przyniosą pożądanych skutków, jeśli u wychowanków nie zaszczepimy trwałego dążenia i potrzeby ochrony przyrody. Ten rzadko stosowany model można określić jako aksjologiczno-perswazyjny ${ }^{8}$; powinien on stanowić podstawę warsztatów proekologicznych i mówimy tutaj raczej o wychowaniu do środowiska niż o tradycyjnej edukacji ekologicznej.

W paradygmacie aksjologiczno-perswazyjnym, w przeciwieństwie do modelu wyżej scharakteryzowanego, edukacja ekologiczna realizowana jest wedle założenia faworyzującego etykę przed ekonomiką, a co za tym idzie faworyzuje wartości moralne przed wartościami ekonomicznymi ${ }^{9}$.

Wcześniejszy, technokratyczny styl realizowania treści ekologicznych miał charakter poznawczo-opisowy, natomiast model aksjologiczno-perswazyjny jest normatywny, ponieważ inwencja pedagogów, animatorów wkładana w rozbudze-

6 Z. HulL, Problemy filozofi ekologii, (w:) Wprowadzenie do filozoficznych problemów ekologii, op. cit., s.81.

7 A. PAPUZIŃSKI, Świadomość ekologiczna a kultura, (w:) Wprowadzenie do filozoficznych problemów ekologii, op. cit., s. 191.

8 Por. Ibidem, s. 193-198.

$9 \quad$ Ibidem, s. 195. 
nie i aktywizację świadomości ekologicznej jest realizowana według pożądanego i uznanego wzorca. Zwraca się tutaj uwagę na zasadnicze rozróżnienie między wartościami akceptowanymi a respektowanymi, a więc takimi, które zostały uwewnętrznione przez wychowanków w postaci „sumienia ekologicznego"lo.

Poza wieloma zaletami tego modelu, należy zwrócić uwagę na pewne wady i wynikające $z$ nich ograniczenia. Często nadmierne deprecjonowanie wartości ekonomicznych i technicznych prowadzi do zbyt radykalnych i utopijnych wizji, zaś rzetelny model edukacji ekologicznej powinien być realistyczny, w przeciwnym wypadku będzie nieefektywny. Rozwój gospodarki, a co za tym idzie i technologii, niestety wiąże się $\mathrm{z}$ niszczeniem natury. Trzeba więc szukać wyjścia z tej sytuacji, w taki sposób, aby odrzucić rozwiązania skrajne.

Jestem zwolennikiem takiego paradygmatu, który w edukacji ekologicznej połączyłby te dwa wyżej scharakteryzowane. Model ten określiłem jako aksjologiczno-scjentystyczny (systemowy). Uważam, iż nie należy rezygnować z dobrodziejstw techniki i dorobku naukowego, bo to przecież od człowieka zależy w jakim celu je wykorzysta. Ponadto aby skutecznie chronić przyrodę, musimy również wiedzieć co tak naprawdę chronimy i dlaczego to czynimy. Należy również poznać skuteczne metody ochrony. W takim aspekcie edukacji ekologicznej, funkcja aksjologiczno-wychowawcza zostałaby połączona z funkcją poznawczą, w obrębie której powinny być przekazywane takie szczegółowe treści, jak: ujęcie struktury i właściwości populacji, biocenoz i ekosystemów, problemy warunkujące istnienie homeostazy biocenotycznej, prawidłowości charakterystyczne dla krążenia materii i przepływu energii w ekosystemach oraz cykle biogeochemiczne ${ }^{11}$.

Paradygmat, którego jestem zwolennikiem, powinien być „trzecią drogą" między, którąś z opozycji: ekonomika - etyka czy etyka - ekonomika. W takim ujęciu wartości ekonomiczne (czy inne wartości pozamoralne, jak: polityczne, kulturowe, poznawcze) nie stoją w opozycji do wartości moralnych (czy na odwrót). Dzieje się tak dlatego, że realizacja wartości ekonomicznych dokonuje się zawsze w sprzężeniu $z$ wartościami moralnymi.

Podobnie wygląda również problem odnośnie kwestii aksjologicznych w ekologii. Model aksjologiczno - scjentystyczny unika radykalnych ujęć tematu, kształtujących relacje w ujęciu: skrajny antropocentryzm czy równie skrajny biocentryzm. W miejsce sporu proponuje antropocentryzm umiarkowany, lub teocentryczny paradygmat ekoetyki ${ }^{12}$, który zapewnia człowiekowi nadrzędne miejsce

10 A. Papuzıński, Życie - Nauka - Ekologia, Bydgoszcz 1998, s.215-218.

1 E. Trzaskowska, O potrzebie i formach edukacji ekologicznej, „Humanizm Ekologiczny”, t. 1, Lublin 1991, s. 99.

12 Por. M. Ciszek, Antropoprioryczna koncepcja chrześcijańskiej etyki środowiskowej oraz jej implikacje $w$ bezpieczeństwie ekologicznym, (w:) Ekofilozofia, bioetyka, etyka biznesu. Aktualne problemy wspólczesności. Pod red. J. Jaronia, Siedlce 2004, s. 39-43. 
w hierarchii wartości, dbając zarówno o zachowanie należnej mu godności, jak i o jego zdrowie i życie. Taki właściwy wzorzec prowadzenia edukacji środowiskowej można upowszechniać również w obszarze edukacji katechetycznej.

\section{Rola katechezy w edukacji ekologicznej rozwijanej na gruncie modelu aksjologicznego}

Unikalną wartość przyrody można ukazać poprzez pryzmat wielu kierunków w etyce środowiskowej. W mojej opinii zwłaszcza dwa z nich przypisują przyrodzie wartość wewnętrzną. Mam tu na myśli nurt biocentryczny i teocentryczny w ekoetyce, ponieważ kierunki te traktują przyrodę w kategorii wartości. Biocentryzm wydaje się jednak wielu etykom nurtem zbyt radykalnym, ponieważ pomniejsza on wartość człowieka na korzyść środowiska przyrodniczego, uważając, iż homo sapiens nie stanowi uprzywilejowanej części biosfery. Naturalnie takiej krytyki nie przyjmują zwolennicy tego kierunku, nie zagłębiając się tutaj w szczegóły chciałbym tylko zauważyć, iż warto w edukacji ekologicznej odwołać się do tych kierunków etycznych, które wyrastają z naszej tradycji kulturowej ${ }^{13}$.

Mam tu na myśli ekoetykę teocentryczną, której zasady z powodzeniem można upowszechniać w edukacji katechetycznej. Przypomnę tylko, iż wspomniany nurt w etyce środowiskowej nakazuje rozpatrywać wszelkie relacje między działaniami moralnymi człowieka a przyrodą, w odniesieniu do Boga, jako Stwórcy przyrody i kosmosu. Przyroda posiada wartość ze względu na Boga, który ją stworzył i utrzymuje ją nadal w istnieniu. Człowiek jako istota wyjątkowa powinien pełnić rolę dobrego strażnika, gospodarza i opiekuna świata przyrody, którą otrzymał w darze od Stwórcy. Natomiast niszcząc przyrodę sprzeciwiamy się Bogu, a więc grzeszymy i czynimy zło. Taki teocentryczny wymiar etyki środowiskowej można również uzgodnić $\mathrm{z}$ antropocentrycznym ujęciem ekoetyki w jej umiarkowanej wersji. ${ }^{14}$

W odpowiedni sposób prowadzona katecheza może przyczynić się do kształtowania duchowej relacji człowieka $z$ naturą, która polega na przekraczaniu tradycyjnego podejścia do środowiska. Jeśli w procesie edukacji katechetycznej będzie upowszechniać się przekonanie, iż przyroda oprócz aspektu fizycznego i materialnego posiada również wymiar duchowy, to istnieją znacznie większe szanse, iż wykształcone wśród uczniów tendencje aksjologiczne, nie zostaną utracone. Na ten duchowy aspekt natury zwracają uwagę wspomniani zwolennicy

13 Naturalnie nie mam zamiaru deprecjonować etyki biocentrycznej w ochronie przyrody, gdyż dorobek przedstawicieli tego nurtu jest na pewno wartościowy, który z powodzeniem można wykorzystać w działaniach z zakresu edukacji ekologicznej.

${ }_{14}$ M. CIsZeK, Antropocentryczne czy teocentryczne podstawy chrześcijańskiej etyki środowiskowej, (w:) Etyka środowiskowa wyzwaniem XXI wieku. Pod red. J.W. Czartoszewskiego, Warszawa 2002, s. 59-71. 
nurtów biocentrycznych, a także innych kierunków nawiązujących do panteizmu czy też panenteizmu, które traktują przyrodę $w$ kategorii sacrum. Nie należy jednak zapominać o proekologicznym charakterze naszej judeochrześcijańskiej tradycji. Katecheci mogą czynnie włączyć się w szkolną edukację środowiskową, zwracając uwagę na ekologiczne walory przesłania religii chrześcijańskiej, a także korzystając z przykładu św. Franciszka propagować pozytywne nastawienie do otaczającej człowieka przyrody.

W tym kontekście warto przypomnieć wypowiedź Jana Pawła II w encyklice Centesimus annus w której zwrócił uwagę, iż „U korzeni bezmyślnego niszczenia środowiska naturalnego tkwi błąd antropologiczny, niestety rozpowszechniony w naszych czasach. Człowiek, który odkrywa swą zdolność przekształcania i w pewnym sensie stwarzania świata własną pracą, zapomina, że zawsze dzieje się to w oparciu o pierwszy dar, otrzymany od Boga na początku w postaci rzeczy przezeń stworzonych. Człowiek mniema, że samowolnie może rozporządzać ziemią, podporządkowując ją bezwzględnie własnej woli, tak jakby nie miała ona własnego kształtu i wcześniejszego, wyznaczonego jej przez Boga przeznaczenia, które człowiek, owszem, może rozwijać, lecz któremu nie może się sprzeniewierzać. Zamiast pełnić rolę współpracownika Boga w dziele stwarzania, człowiek zajmuje Jego miejsce i w końcu prowokuje bunt natury, raczej przez niego tyranizowanej, niż rządzonej" ${ }^{15}$ (CA 37).

\section{Zakończenie}

Kończąc rozważania, chciałbym jeszcze raz podkreślić wyjątkową wartość etyki środowiskowej w sferze szerzenia świadomości ekologicznej, bowiem bez chęci ochrony przyrody nawet najlepiej skonstruowane prawo ochrony przyrody, nie uchroni nas przed dalej postępującą degradacją natury. W takim ujęciu uwidacznia się szczególna rola katechezy w kształtowaniu właściwych relacji człowieka z przyrodą, która przyczynić się może do wykształcenia u wychowanków „sumienia ekologicznego".

15 JAN PAWEe II, encyklika, Centesimus annus, Rzym 1991, p. 37. 